\title{
THE DEVELOPMENT OF INDIVIDUAL CRIMINAL RESPONSIBILITY UNDER INTERNATIONAL LAW: LESSONS FROM NUREMBERG AND TOKYO WAR CRIMES TRIALS
}

\author{
William Edward Adjei* \\ Ghana Institute of Management and Public Administration, Accra, Ghana, E-mail: \\ weadjei@yahoo.com
}

(Received: April 2020; Accepted: June 2020; Published: June 2020)

\begin{abstract}
One of the most significant developments in international law was the establishment of Special Tribunals that could bring to justice individuals allegedly responsible for "grave breaches" and violations of the law against humanity. This is, undoubtedly, a recent global development that has challenged the issues of impunity and sovereignty. Since the Nazis' atrocities and the Nuremberg trials, war crimes law has broadened its scope and has recognized a number of offenses considered as "international crimes" and which have also come to be described as "genocide". However, although intended to put an end to the politics of impunity for the perpetrators of these crimes, a number of signatory states are reluctant to bring to justice those responsible for these defined international crimes. Indeed, the jurisprudence developed in these Special Tribunals provided an impetus for the development of the Rome Statute for the International Criminal Court (ICC). More specifically, it has been argued that war crimes and crimes against humanity are committed by men, not by abstract entities, and only by punishing individuals who commit such heinous crimes can the provisions of international law be enforced and realized. However, a perfectly reasonable case can be made that the creation of these tribunals does represent a new era in international law.
\end{abstract}

Keywords: International humanitarian law, jurisdictional immunity, sovereignty, genocide, prosecution, criminal responsibility.

\section{Introduction:}

The new approach to "internationalization"

Individual criminal responsibility for war crimes, genocide, crimes against humanity and crime of aggression is today undisputed and complex [1]. So far as jurisdiction is concerned, the role of international law is still bedeviled by the profound feeling

\footnotetext{
*Corresponding author: William Edward Adjei.E-mail: weadjei@yahoo.com
}

Copyright $@ 2020$ The Author(s). Published by VGWU Press

This is an Open Access article distributed under the terms of the Creative Commons BY 4.0 license (Creative Commons - Attribution 4.0 International - CC BY 4.0) which permits unrestricted use, distribution, and reproduction in any medium, provided the original author and source are credited.

69 Sciendo Journal of Legal Studies Volume 25 Issue 39/2020 
Adjei, W.E., (2020)

"Vasile Goldiş" Western University of Arad

The development of individual criminal responsibility under international law: Lessons from Nuremberg and Tokyo war crimes trials

among rulers of states who think that certain types of disputes are not "justiciable", in the sense that these matters are considered to be socio-political rather than legal, and therefore not an appropriate subject-matter for decision by a court of law. Conflicts in countries such as Catholics of Northern Ireland, Yugoslavia and the Soviet Union, Rwanda, Sierra Leone, Afghanistan, Iraq, Bosnia-Herzegovina, Kosovo, Chile, Egypt, Libya, Liberia, Turkey, Democratic Republic of Congo (DRC), Darfur of Western Sudan, Kenya, Republic of Central Africa, and Cote D'lvoire reveal that most of the contemporary wars are not fought between two states, but rather between parties inside states, often orchestrated by some irresponsible leaders. It may also be mentioned here that global consciousness to end state impunity, has necessitated the creation of an international criminal justice system that complemented and reinforced national legal systems. However, as we have also seen, this approach of 'internationalization' as reflected in the decisions of the various tribunals marked the beginning of an important legal evolution, which was later defined with the setting-up of the ad hoc Tribunals for the former Yugoslavia and for Rwanda, and with the diplomatic conference that adopted the Rome Statute of the International Criminal Court. This feature is highlighted by various tribunals as a significant development in international law [2]. In developing tribunal's jurisprudence on individual accountability at the 1946 Nuremberg Trial, Justice Robert Jackson reiterating the rationale for criminal punishment in international law held that:

"crimes against international law are committed by men, not by abstract entities, and only by punishing individuals who commit such crime can the provisions of the international law be enforced" [3].

The Special Tribunal also relied on Article IV of the 1948 Convention on the Prevention and Punishment of the Crime of Genocide, which indicated that:

"persons committing genocide or any of the other acts enumerated in art.III

shall be punished whether they are constitutionally responsible rulers, public officials or private individuals [4]."

It should, for the sake of clarity, be stressed that the above quotations depict the reasoning developed by the IMT that individuals or serving heads of state and other public officials who commit most serious crimes of concern to the international community must not go unpunished [5]. This ruling also underscores the point made in The Prosecutor v. Bosco Ntaganda (2019) [6], where the ICC in its most recent decision referred to the Preamble of the Rome Statute, noting that "retribution" and "deterrence" are mechanisms to discourage a convicted person from recidivism as well as to ensure that those who may consider committing similar crimes are dissuaded from doing so [7]. More controversially, in Arrest Warrant of 11 April 2000 (Democratic Republic of Congo v. Belgium), ICJ held that no head of state,

70 S sciendo Journal of Legal Studies Volume 25 Issue 39/2020 ISSN 2457-9017; Online ISSN 2392-7054.

Web: publicatii.uvvg.ro/index.php/jls. Pages $69-97$ 
Adjei, W.E., (2020)

"Vasile Goldiş" Western University of Arad

The development of individual criminal responsibility under international law: Lessons from Nuremberg and Tokyo war crimes trials

head of government, or minister of foreign affairs while in office may be arrested by order of the national court of another state or preliminary measures, such as the issue of international circulation of an arrest warrant taken against such person [8]. Such pronouncements in a large measure have undermined justice and contributed to diplomatic immunities and state impunity. We will return to this in a moment.

Conceptually, a number of cases considered in this work tend to reveal international law scholarship that has not yet fully come to grips with the interrelationship of international criminal law and the jurisprudence of individual criminal responsibility [9]. This claim is apparent in cases such as Hissene Habre of Chad, Alberto Fujimori of Peru, Akayesu, Desire Munyaneza, Ricardo Cavallo, Nicolas Carranza, Augusto Pinochet [10], Prosecutorv. Kambanda [11], Prosecutorv. Tadic [12], Democratic Republic of Congo v. Belgium [13], Prosecutor v. Taylor [14], Prosecutor v. Bemba [15], Prosecutor v. Thomas Lubanga Dyilo (2012), and most recently the Prosecutor v. Bosco Ntaganda (2019) [16]. Again, the most striking feature of the findings regarding the aforementioned cases has revealed insufficient clear effective mechanisms to hold individuals accountable for the most serious humanitarian catastrophes both at the international and national levels [17]. It is obvious that most of these cases raise a number of complex and potentially litigious issues. Again, the issues raised in these cases have the potential of undermining global commitment to security, stability and individual liberties for disadvantaged and marginalized groups.

Attempts to enforce individual criminal responsibility in the Hague Conference of 1899 , and again in 1907, were constrained by notions of state sovereignty. The legal effect and enforceability of this concept can be controversial as the Nuremberg judges demonstrated in 1946, "The Hague Convention nowhere designates such practices [methods of waging war] as criminal, nor is any sentence prescribed, nor any mention made of a court to try and punish offenders" [18]. The heinous activities of Nazi Germany, Rwanda [19], the Former Yugoslavia [20], the Pol Pot regime in Cambodia [21], the use of poison gas by Iraq against its Kurdish population and the case concerning the Arrest Warrant (Congo v. Belgium) (2002) are among the many atrocious crimes perpetrated either by sitting Head of State or people in high public offices and are prosecuted. In March 2009 the ICC issued an arrest warrant for Omar Hasan Ahmad Al Bashir, the President of Sudan, on charges of crimes against humanity and war crimes. This was the first time the ICC had indicted a sitting Head of State. Since then further arrest warrants have been issued in respect of other Heads of State, namely Muammar Quadaffi, former Libyan Head of State, who was subsequently killed in October 2011, and Laurent Gbagbo, former president of Cote D'lvoire, who was transferred into the custody of the Court in November 2011. The former dictator of Iraq, Saddam Hussein, was also convicted and executed for crimes 
Adjei, W.E., (2020)

The development of individual criminal responsibility under international law: Lessons from Nuremberg and Tokyo war crimes trials

against humanity by the Iraqi Special Tribunal [22]. In such situations, Broomhall has remarked that such inhuman and degrading acts of statesmen are unfortunate and undermined the international community's interest in peace and security and "shocked the conscience of mankind" [23]. Although it is clear that for many people, enforcement of individual responsibility in international law is still more of a dream than reality, yet some basic template has been created from which a whole new jurisprudence is beginning to take root.

What I propose to do, is demonstrate how individual criminal responsibility has evolved as a concept and is evolving as a legal doctrine in international law; and to show what difference international crimes, properly interpreted, can make. I will do this by first, providing some historical background to the concept which has in history made an indispensable contribution to international law. Second, I will discuss the application of the Nuremberg and Tokyo war trial principles to constitutional as well as humanitarian law cases. The principal lesson from these tribunals is to ensure individual culpability to the Rome Statute principles on which the protection of human rights depends. It also sets out its overarching theme of exploring the relationship between law and immunity. Here, some relevant IMT and ICC cases provide an overview of the academic debate on the impact of the 'internationalization' of war crimes. This will be followed by a discussion of enforcement mechanisms through international and national courts. The existing role of national courts in dealing with international crimes will be contrasted with various tribunals outlined above under the 'internationalization' of crimes.

\section{Defining and identifying international crimes}

As in the above argument of the central case-law, the precise definition as to what constitutes international crime remains contested. In the previous chapter, we examined the phenomenon that necessitated the creation of an international system of justice. An attempt has been made to expose areas of international law that deal with issues of immunity for public officials, immunity for representatives of the state and massive violations of human rights [24]. This Chapter again introduces you to the general topic of what war crime is, and how ideas of war interact with the law. It begins by considering the meaning and scope of individual criminal responsibility and the basic understanding of international crime within the Nuremberg and Tokyo war crimes trials. Here, we will address some of the implications of Chapter 1, dealing with the issues generated by the development of individual criminal responsibility and the effect of embracing tribunal judgments within international law. In Chapter 1 we looked at the importance of legal evolution in creating international courts to address humanitarian and international crimes. This Chapter, however, will concentrate on the historical development of the concept and how it

72 sciendo Journal of Legal Studies Volume 25 Issue 39/2020 ISSN 2457-9017; Online ISSN 2392-7054.

Web: publicatii.uvvg.ro/index.php/jls. Pages $69-97$ 
Adjei, W.E., (2020)

"Vasile Goldiş" Western University of Arad

The development of individual criminal responsibility under international law: Lessons from Nuremberg and Tokyo war crimes trials

has been interpreted by various tribunals/courts and entrenched in national court practices. We will use the terms "individual responsibility" and "personal accountability" interchangeably, although not everyone would agree that they have the same precise meaning.

Undoubtedly, the scope and meaning of Article1 of the Draft Code of Offences against the Peace and Security of Mankind is broad: it applies to offenses against the peace, and security of mankind articulated by the International Law Commission" [25]. It is, however, confirmed in Article 1 of the 1996 text which states that "crimes against the peace and security of mankind are crimes under international law, and punishable as such, whether or not they are punishable under national law" [26] Also under Article 2, "a crime against peace and security of mankind entails individual responsibility." The underlying basic assumption of this concept is founded upon the principle of personal culpability, that is, no one may be held criminally responsible for acts or transactions in which he/she has not personally engaged or in some other way participated (nulla poena sine culpa) [27]. The principles laid down in the Rome Statute were taken further by the International Criminal Tribunal for the Prosecution of Persons Responsible for Serious Violations of International Humanitarian Law Committed in the Territory of the Former Yugoslavia (ICTY 1991) [28] and the International Criminal Tribunal for Rwanda (ICTR). In the case of Prosecutor v. Dusko Tadic [29], the question of personal culpability was raised and the Appeals Chamber ruled that "nobody may be held criminally liable for acts or transactions in which he/she has not personally engaged or in some other way participated. In its previous rulings in Tadic and Delalic, the ICTY had recognized that the persecution could encompass acts from killing to limitations on the type of professions open to the targeted group, and acts of physical, economic or judicial nature, in violation of the right of an individual to equal enjoyment of basic rights [30]. The same principle is reflected in Article 7(1) of the Statute of the International Criminal Tribunal for the Former Yugoslavia" [31]. The concept is further incorporated in Article 25 (1) of the Rome Statute [32] which states that "the court shall have jurisdiction over natural persons pursuant to the Statute" [33] and Article 25 (2) continues that: "a person who commits a crime within the jurisdiction of the court shall be individually responsible and liable for punishment under the Statute whether they are constitutionally responsible rulers, public officials or private individuals" [34]. Article 27(1) further provides: "This Statute shall apply equally to all persons without any distinction based on official capacity." Individuals may also be held responsible for "grave breaches" of the 1949 Geneva Red Cross Conventions; 1977 Additional Protocols I and II; and also for the commission of such acts such as drug trafficking, terrorism and acts against state diplomats [35], and their contents will be discussed further below. 
Adjei, W.E., (2020)

"Vasile Goldiş" Western University of Arad

The development of individual criminal responsibility under international law: Lessons from Nuremberg and Tokyo war crimes trials

\subsection{Understanding individual criminal responsibility: A brief historical overview}

This section briefly examines the historical development of individual criminal responsibility under international law, describing some of the major political events and decisions which have contributed in shaping its legal and constitutional structure. It should be noted that the idea of trying international criminals in an international forum evolved at the end of World War I. A number of relatively distinct periods or phases of the developmental process have been identified, and different theories have emerged to explain the various phases, beginning with the Versailles Peace Treaty which was contained in Article 27. At this stage, there was a statement of the responsibility of the German Emperor Kaiser Wilhelm II relating to the "supreme offense against international morality" [36] and the sanctity of treaties and proposed the establishment of a tribunal to try him [37]. Thus, although this provided the basis for the establishment of a special tribunal to deal with humanitarian and war crimes, this did not occur because of the protection that the Kaiser received from Holland [39]. However, at the end of the Second World War, leaders of the Nazi and Japanese regimes were brought before the International Military Tribunals in Germany and Japan. An international conference on military trials held at London, which resulted in the Nuremberg Charter, set up the court to prosecute individuals for crimes against peace, war crimes, and crimes against humanity. With respect to Tokyo, General MacArthur, Supreme Commander of the Allied Powers in Japan, approved in an executive order the Tokyo Charter setting out the jurisdiction of the IMT for the Far East which also tried crimes against peace and humanity. What is evident is that, as a result of these developments, two areas were further developed; civil conflict resulted in the establishment of "ad hoc criminal tribunals". The UN Security Council by Resolution 827 set up the ICTY in 1993 and in 1994 by Resolution 955 established the ICTR. Both resolutions had statute of the tribunals appended to them which authorized trying individuals for genocide, crimes against humanity, and war crimes. This was an extraordinary development, as the Security Council interpreted its mandate of preserving peace and security as extending to the establishment of international criminal tribunals. Similarly, the reasoning was developed by the ICJ in Tadic, a jurisdiction appeals decision in the ICTY.

\subsection{Exploring the entrenchment of international criminal law [40]}

As has been noted earlier, the jurisdictional experience of Nuremberg and Tokyo marked the start of a gradual process of precise formulation and consolidation of principles and rules during which states and international organizations (namely, the United Nations and the International Committee of the Red Cross) launched an 
Adjei, W.E., (2020)

"Vasile Goldiş" Western University of Arad

The development of individual criminal responsibility under international law: Lessons from Nuremberg and Tokyo war crimes trials

initiative to bring about codification through the adoption of treaties. As maintained, the trials were very important, not only because they gave some victims and survivors of victims of human rights abuses a sense of international moral response to their spiritual and moral plight, but also because they helped to establish the legal basis for personal accountability, in particular during the war [41]. They reflect on how criminal responsibility has been developed in the case-law of international criminal tribunals and courts. These courts, as noted illuminate and analyze the rules on individual responsibility in international law. All these claims will be explained. The Declaration of St. James was the first step leading to the establishment of the International Military Tribunal (IMT) at Nuremberg. At the end of World War II, on August 8, 1945, the four major Allied Powers reached an agreement for the Prosecution and Punishment of the Major War Criminals of the European Axis with an annex of the Charter of the International Military Tribunal (Nuremberg Tribunal) [42]. Article 6 of the Charter of IMT [43] recognized explicitly that individuals were to be held responsible for crimes against the peace, war crimes and crimes against humanity [44]. This was evident in their judgment:

"International law is concerned with the actions of sovereign states, and provides no punishment for individuals; and further, that where the action in question is an act of state, those who carry it out are not personally responsible but are protected by the doctrine of the sovereignty of the state. In the opinion of the Tribunal, both these submissions must be rejected. That international law imposes duties and liabilities upon individuals as upon states have long been recognized....the very essence of the Charter is that individuals have international duties which transcend the national obligations of obedience imposed by the individual State. He who violates the laws of war cannot obtain immunity while acting in pursuance of the authority of the state, if the state in authorizing action moves outside its competence under international law" [45].

As will be seen, in both Nuremberg and Tokyo war crimes trials, the judges were of the opinion that the lower ranking state officials should not be held responsible in respect of this crime, because they are lacking in mental element [46]. In effect, common foot soldiers cannot be responsible for the crime of aggression [47]. The reasoning was that in most cases they could not be aware, by virtue of their position, of aggressive intentions of their superiors. Only the top-ranking officers and public officials are aware of the aggressive plans of a country. The place of the individual in the international criminal justice system will be examined more fully below.

As early as 11 December 1946, the UN General Assembly adopted by unanimous vote Resolution 95(1), entitled "Affirmation of the Principles of International Law Recognised by the Charter of the Nuremberg Tribunal [48]". This meant that in the 
Adjei, W.E., (2020) war crimes trials

General Assembly's view the Tribunal had taken into account already existing principles of international law, which the court had only to "recognize". It was also a commitment to have these principles codified by the International Law Commission (ILC), a subsidiary organ if the UN General Assembly. Consequently, the IMT took an extremely controversial view of Nullum crimen in 1946 with regard to the issue of the criminality of aggressive war. The Tribunal saw it as "a principle of justice" and merely stated that it would be unjust to let those who violate treaties go unpunished since "the attacker must know that he is doing wrong" [49]. In effect, it evaded the critical distinction between violations of international law and individual criminal culpability for those violations.

One of the basic tenets of contemporary criminal responsibility was developed and pronounced by the Nuremberg Tribunal that the official position held by the defendant does not shield him from responsibility or act as a mitigating factor in punishment [50]. The Tribunal also rejected the argument that the crimes in issue were protected by the doctrine of the sovereignty of the state. It is stated that the act of state immunity, which protects the representatives of a state, is not applicable to acts which are regarded as criminal under international law. The same principles were enshrined in the Charter of the Tokyo Tribunal and in the Control Council Law No. 10, the latter of which governed many significant prosecutions of Nazis below the level of those tried by the IMT [51]. The IMT Charter further eliminated the defenses of command responsibility and superior orders. The defense of superior orders could only be considered in mitigation of punishment if the Tribunal determined that justice so required [52]. This was not absolute because it depended on the discretion of the Tribunal and the circumstances and facts of each case.

The issue of whether superior orders should provide any form of defense was first considered at the trial of Sir Peter Von Hagenbach in 1447, who was convicted of crimes against "the laws of God and man including murder and rape, before a tribunal of 28 judges [53]. Several years later, the Nuremberg Tribunal noted that the doctrine of immunity of heads of state typically was coupled with superior orders defense. It was observed that the combination of these two doctrines "means that nobody is responsible [54]". If superior orders were admissible as a defense against culpability, international legal rules would in effect be subordinated to national law since soldiers could claim that their violations of international criminal law were allowed by the higher authority of their state. Higher officials themselves could be exempted until those individuals acting as heads of state could claim the defense of act of state, i.e. that their orders do not inculpate them since they were made within the sphere of state sovereign and that they enjoy immunity from prosecution on the basis of international law [55].

76 S sciendo Journal of Legal Studies Volume 25 Issue 39/2020 ISSN 2457-9017; Online ISSN 2392-7054. 

war crimes trials

The Post-Nuremberg trial maintained the principles eliminating defense of superior orders. This is well illustrated by the case-law concerning lawful orders and criminal liability. In the Hostage Case (United States v. Wilhelm List et al) [56], the American Tribunal held that if the legality of the order was not known to the inferior and he could not reasonably have been expected to know its legality, no wrongful intent necessary to the commission of a crime exists and the inferior will be protected. But the general rule is that members of the armed forces are bound to obey only the lawful orders of the commanding officers, and they cannot escape criminal liability by obeying a command which violates international law and outrages fundamental concepts of justice.

Although the IMT did not allow the defense of superior orders, it could be pleaded in certain circumstances. The true test, which is found in varying degrees in the criminal law of most nations, is not the existence of the order, but whether in fact, the moral choice was possible to the defendant [57]. This was the genesis of contemporary individual criminal responsibility. It was formulated to hold perpetrators of serious crimes accountable for their acts, irrespective of their status or positions of authority.

\subsection{Nature of the concept after Nuremberg: The enforcement of international judgments}

The UN system through the International Law Commission (ILC) adopted in 1950 a report on the said principles, of which Principle I states that: "any person who commits an act which constitutes a crime under international law is responsible thereof and liable to punishment." It constitutes official recognition of the fact that an individual - in the broadest sense, any person - may be held responsible for having committed a crime. It further provides that a person who acts in his capacity as Head of State or as a public official and one who acts on the orders of the government or a superior is not thereby relieved of responsibility [58]. The affirmation of Principles III and IV are premised on the provisions of Articles 7 and 8 of the IMT Charter, which eliminates Head of State immunity, hence apportioning command responsibility, even to a Head of State and other government officials, though in the latter case, mitigation of punishment may be considered "if the tribunal to decide whether or not the individual had a moral choice to comply with a superior's order. Principle VI (Crimes against Peace, War Crimes and Crimes against Humanity) codified Article 6 of the IMT Charter and formed the basis of individual criminal responsibility for crimes under international law, and represents the foundation of international criminal law.

Broadly speaking, these principles were extremely influential in the evolution of the law and procedure of more contemporary institutions, namely; the International 
Adjei, W.E., (2020)

"Vasile Goldiş" Western University of Arad

The development of individual criminal responsibility under international law: Lessons from Nuremberg and Tokyo war crimes trials

Criminal Tribunal for Former Yugoslavia (ICTY), the International Criminal Tribunal for Rwanda (ICTR) and the International Criminal Court (ICC) [59]. The principles were not only an inspiration for the statutes of the above institutions but also set the trend in national prosecutions - including those in the United States for the My Lai killings in the Vietnam war; in Israel when the Kahan Commission investigated the invasion in Lebanon which led to massacres in the Palestinian refugee camps, Sabra and Shatilla; in Germany, in the case of Honneker and the Pinochet extradition case in the United Kingdom [60]. In 2012, the ICC handed down its first verdict in the case of The Prosecution v. Thomas Lubanga Dyilo.

\section{(a) Command or superior responsibility}

Command is the primary mechanism through which superiors can be held criminally responsible for crimes perpetrated by their subordinates. It is an important tool in punishing superiors for lack of control or supervision over those under their command or authority [61]. In re Yamashita [62], it was held that military commanders have an affirmative duty to control their subordinates, ensuring their compliance with the laws of war and that where such a duty exists, a charge alleging less than personal participation in, or ordering of, an act in violation of the laws of war is a violation of the laws of war.

Superior responsibility incurs criminal responsibility for violation of the laws of war. The importance of this principle is that its value lies in the recognition that failure of duty can generate criminal responsibility [63]. This involves crimes either by highlevel military or political leaders or low-level officials or military personnel, who perpetrate crimes because superior authorities do not prevent, or they tolerate or fail to repress them. At present, the notion is firmly embedded in international humanitarian law [64] as well as in the Statute of the ICTY, ICTR and the ICC [65]. It covers superior responsibility for any international crime committed by subordinates, including but not limited to war crimes, crimes against humanity, genocide, etc.

The Statutes of the ICTY and ICTR clearly established criminal responsibility for civilian superiors who act on a comparable footing with military command responsibility. The common test is to apply the criteria of knowledge or awareness, power or authority and acceptance or negligence [66]. However, under Article 28 of the Rome Statute, the difference is made between civilian superior responsibility and military superior. The military criminal responsibility provides for an extra test of "should have known" whereas the civilian one has no such test [67].

The concept of superior responsibility consists of three aspects (i) a functional aspect, a superior's position must entail a duty to act (ii) a cognitive aspect; a superior must have known, or should have known of the crime and (iii) an operational aspect; a superior must have failed to act [68]. In Prosecutor v. Delalic (Celebici Case) [69],

78 S sciendo Journal of Legal Studies Volume 25 Issue 39/2020 ISSN 2457-9017; Online ISSN 2392-7054.

Web: publicatii.uvvg.ro/index.php/jls. Pages $69-97$ 
Adjei, W.E., (2020)

The development of individual criminal responsibility under international law: Lessons from Nuremberg and Tokyo war crimes trials

the Trial Chamber held that from the text of Article 7 (3) of the ICTY Statute it could be taken that the concept of "superior" is not restricted to military superiors. The use of the term "superior" and the affirmation of individual criminal responsibility for Heads of State or responsible government officers in Article 7 (2) was found to indicate that superior responsibility extends beyond military commanders to political leaders and other non-military superiors in positions of authority [70].

\section{(b) Head of state immunity}

Accountability for human rights violations is now a global issue and there is a shift of focus from state responsibility to individual responsibility. It would, therefore, become meaningless if individuals could hide behind the sovereignty of the state. The trend in international law is to rule out all barriers that would allow any form of impunity for violations of humanitarian law [71]. Indeed, the wind of change is blowing and dictators will not escape liability easily anymore [72]. The Charter of the IMT provided that the defendants were individually responsible for the commission of serious crimes, "notwithstanding their positions as heads of state [73]". The Nuremberg Judgment stated that: "the principle of international law which under certain circumstances protects the representatives of a state cannot be applied to acts that are condemned as criminal by international law. The authors of these acts cannot shelter themselves from punishment [74]".

The fact that the official position of the perpetrator does not entail state immunity regarding egregious human rights violations is stipulated in a number of international instruments. The 1948 Genocide Convention expressly eliminates Head of State immunity [75]. The International Covenant on Civil and Political Rights (ICCPR) forbids torture and disallows official immunity [76]. This principle was tested in the case of Regina v. Bow Street Metropolitan Stipendiary Magistrate, ex-parte Pinochet Ugarte (No. 3) [77], where the UK House of Lords held that a former Head of State would only enjoy immunity for those acts carried out within his official function as Head of State. However, what constitutes an official act and what is a personal act remains unresolved. I $t$ was also held that neither an individual nor a state could claim immunity for acts prohibited by an international convention to which the state claiming the immunity is a contracting party. See also the Case Concerning the Arrest Warrant (2002) which endorsed the immunity of a DRC national who at the time of his offense was the Minister for Foreign Affairs [78]. This point was further underscored by the indictment of Slobodan Milosevic [79] by the ICTY, as head of state, for war crimes and crimes against humanity. In the Prosecution v. Charles Ghankay Taylor [80], Taylor was indicted by the Special Court for Sierra Leone (SCSL) in 2003, when he was still president of Liberia, for participation in a joint criminal enterprise in Sierra Leone, for war crimes, crimes against humanity and serious violations of international humanitarian law, for which he was individually 
Adjei, W.E., (2020)

"Vasile Goldiş" Western University of Arad

The development of individual criminal responsibility under international law: Lessons from Nuremberg and Tokyo war crimes trials

held responsible. Taylor filed a motion to squash the indictment on grounds of Head of State Immunity. The Appeal Chamber, relying on Article 6 (2) [81] of the SCSL Statute held that, Taylor's immunities ratione personae could not constitute a bar to the jurisdiction of the SCSL and that the principle of sovereign equality of states does not prevent a Head of State from being prosecuted before an international criminal tribunal or court. In Republic of Philippines v. Marcos (No. 1) the US Court of Appeals for the Second Circuit held that the Marcoses, the deposed leader and his wife, were not entitled to sovereign immunity. This was confirmed in US v. Noriega where the District Court noted that head-of-state immunity was grounded in customary international law, but, in order to assert such immunity, a government official must be recognized as head of state, which had not happened in this case.

(c) Superior orders

Prior to the Nuremberg Judgment, the position was established in the Llandovery Castle [82], that a subordinate obeying an order is liable to punishment if it was known to him that the order of the superior involved the infringement of civil or military law. The Llandovery Castle constitutes the first international precedent in which the conditional liability approach was recognized. At Nuremberg, although the military tribunal did not allow the defense of superior orders in the cases before them, it is submitted that under certain circumstances a plea of superior orders could exempt the defendant from liability [83].

The ICTY Statute in Article 7 (4) and ICTR in Article 6 (4) have adopted the Nuremberg position that superior orders are not a defense. However the Rome Statute Article 33 (1) (c), superior orders may be a defense if the order was not manifestly unlawful. It is clear that obedience to illegal orders cannot exonerate a perpetrator from criminal responsibility. The soldier who pulls the trigger; the commander who gives the order, or knows that the crime is going to be committed and does not use his authority to stop it from occurring; the civilian decision-maker who makes the policy generating the criminal act, must all account for their criminal acts [84].

It is submitted here that the norm of exclusive state responsibility in international law for war crimes gave way to the principle of individual responsibility as the Nuremberg Charter gained recognition that heinous crimes ought not to go unpunished. It is only through punishing individual perpetrators that the provisions of international law may be preserved and enforced. It is therefore vital to acknowledge herein, for the purpose of appreciating the present legal concept of individual responsibility in international law that the Nuremberg Charter is the true source of individual criminal responsibility for war crimes, crimes against peace and crimes against humanity.

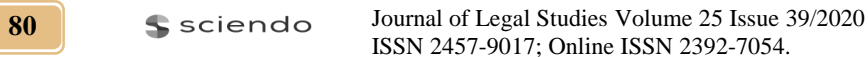
ISSN 2457-9017; Online ISSN 2392-7054.
Web: publicatii.uvvg.ro/index.php/jls. Pages $69-97$ 
Adjei, W.E., (2020)

"Vasile Goldiş" Western University of Arad

The development of individual criminal responsibility under international law: Lessons from Nuremberg and Tokyo war crimes trials

\section{3. "Individual criminal responsibility" and National Courts}

The previous Chapter focused on what constitutes international crimes, scope and meaning of "individual criminal responsibility". The present Chapter will consider the role of national courts and their effective contribution to international law in terms of protection of rights of the relevant parties. The exercise of jurisdiction in relation to the gravity of the crime will be evaluated; some arguing in favor of national prosecution [85] while others argued in favor of international prosecution [86]. While there are valid reasons for national remedies, the topics discussed within this Chapter raise important issues concerning the very nature of national courts. Here, one is concerned with the way in which the actions of the State itself can infringe international law.

Universal jurisdiction allows any nation to prosecute offenders for certain crimes even when the prosecuting nation lacks a traditional nexus with either the crime; the alleged offender, or the victim. It is a doctrine that was developed to address piracy that menaced international trade and justified its application by deeming piracy hostis humani-generis [87]. The rationale behind this approach was the need to fight jointly against a form of criminality that affected all states. The same jurisdictional ground was included in the 1949 Geneva Conventions, the 1984 Convention against torture and a string of international treaties [88]. Under Article 5(1) of the Torture Convention, parties are required to establish jurisdiction over offenses of torture when the offense is committed in its territory when the alleged offender is a national, or when the victim is a national of that state. Article 5(2) requires the parties to establish jurisdiction over the offense where the alleged offender is present in any territory under its jurisdiction if it does not extradite him. The parties are authorized to either prosecute or extradite the alleged offender [89]. The judgment of the House of Lords in $R v$. Bow Street Metropolitan Stipendiary Magistrate, ex parte Pinochet Ugarte [90], was the first case where a former head of state was individually held accountable for torture and prosecuted in a national court of another country for acts committed in another State. Lord Browne-Wilkinson stated that the jus cogens nature of the international crime of torture justifies States in taking universal jurisdiction over torture wherever committed [91].

The crimes over which such universal jurisdiction may be exercised are of such magnitude that they warrant universal prosecution and repression. Likewise in Attorney-General of Israel v. Eichmann [92], the Supreme Court stated that: "not only do all the crimes attributed to the appellant bear an international character but their harmful and murderous effects were as embracing and widespread as to shake the international community to its very foundation. The state of Israel therefore, was entitled, pursuant to the principle of universal jurisdiction and in the capacity of a guardian of international law and an agent for its enforcement, to try the appellant" 
The development of individual criminal responsibility under international law: Lessons from Nuremberg and Tokyo war crimes trials

[93]. Any state is, therefore, authorized to substitute itself for the natural judicial forum, namely the territorial or national state, should neither of them bring proceedings against the alleged author of an international crime [94].

\section{Impedements inhibiting national legal machinery: The problem of international criminal law (ICL)}

There are numerous factors that inhibit the efforts of national courts in the prosecution of international crimes [95]. Commentators supporting the creation of an effective national justice system and international prosecution believe that national courts or other procedures cannot be relied upon or trusted. Thus, an attempt at establishing a national accountability mechanism has come to naught due to lack of political will, and culture of impunity. These perceived obstacles are dealt with below and they include: (a) immunities (b) lack of implementing legislation for international treaties, (c) legislation granting amnesty and (d) statutes of limitation.

(a) Immunities

It is commonly accepted that state officials are immured in certain circumstances from the jurisdiction of foreign states. This immunity therefore, operates as a jurisdictional or procedural bar and prevents courts from indirectly exercising control over acts of the foreign state through proceedings against the offending individual, thereby inhibiting the enforcement of individual criminal responsibility of the alleged offenders. These immunities are orchestrated, firstly, from the customary international law of state immunity, which is concerned with preventing states from control over the public acts of other states. Secondly, under international customary law and applicable treaties, diplomatic agents of states are entitled to immunity from the jurisdiction of the foreign state to which they are accredited [96]. While some officials enjoy broad immunity because of their status or office (immunity ratione personae) [97], the immunity of others relates only to acts performed in their capacity (immunity ratione material), this will be elaborated below.

The principle that immunity ratione personae subsists even when it is alleged that the senior serving official has committed an international crime has been orchestrated by some national courts. Muammar el-Ghaddafi case [98] is a prime example, where it might be said that the court did take into account the immunity of a senior serving official. This is a case relating to bombing of a French airliner in 1989, in which 156 passengers and 15 crew members died, the French Court of Cassation dismissed the case on grounds of immunity. The court held that a state official possessing immunity ratione personae is not subject to the criminal jurisdiction of a foreign state when it is alleged that he/she has committed an international crime [99]. To this we could add Fidel Castro's case [100] where the

82 sciendo Journal of Legal Studies Volume 25 Issue 39/2020 ISSN 2457-9017; Online ISSN 2392-7054.

Web: publicatii.uvvg.ro/index.php/jls. Pages $69-97$ 
Adjei, W.E., (2020)

The development of individual criminal responsibility under international law: Lessons from Nuremberg and Tokyo war crimes trials

Spanish Court held that, as long as Castro was an incumbent head of state, he could not be prosecuted in Spain, not even for international crimes envisaged under the Spanish Law of 1985. Also, in the case of the Democratic Republic of Congo v. Belgium (Case Concerning the Arrest Warrant of 11 April 2000) [101], the ICJ stated that: "it has been unable to deduce from state practice that there exists under customary international law any form of exception to the rule offering immunity from criminal jurisdiction and inviolability to incumbent Ministers of Foreign Affairs, where they are suspected of having committed war crimes or crimes against humanity" [102]. However, recently, the Special Court for Sierra Leone decided to deny the claim for immunity made by the former President of Liberia, Charles Taylor [103].

\section{(b) Lack of implementing legislation}

Another related impediment that has been identified is the lack of implementing legislation. Normally, national courts tend to require either a national statute defining the crime and granting them jurisdiction over it or if a treaty has been ratified on the matter by a state, the passing of implementing legislation enabling courts to fully apply the relevant treaty provisions. In adopting a jurisdictional, contextual approach, the Paris Court of Appeal in Reporters Sans Frontieres v. Mille Collines [104], held that it lacked jurisdiction over genocide, grave breaches of the 1949 Geneva Conventions, crimes against humanity and torture allegedly committed abroad by foreigners. As far as genocide, war crimes and crimes against humanity were concerned, the Court held that it had no jurisdiction because: "in the absence of provisions of domestic law, international customary law cannot have the effect of extending the extraterritorial jurisdiction of the French courts. In that respect, only the provisions of international treaties are applicable under the national legal system provided they have been duly approved or ratified by France and, on account of the contents, the provisions of such treaties produce a direct effect."

It has already been pointed out that a number of states have failed to pass legislation to implement duly ratified international treaties. National courts are not, therefore, prepared to exercise jurisdiction if express national legislation to this effect is lacking and yet other states have passed legislations that restrict or narrow the scope on grounds of jurisdiction lay down in international treaties. Article 27 of the 1969 Vienna Convention on the Law of Treaties clearly states that "a party may not invoke the provisions of its internal law as justification for its failure to perform a treaty". In the case of Hissene Habre [105], former president of Chad, the Supreme Court of Senegal refused to apply Article 6 of the 1984 Convention on Torture [106]. This Convention had been ratified by Senegal on the $16^{\text {th }}$ June 1986 and had become part of Senegalese legislation. Habre was charged with war crimes, crimes against humanity, and torture, but the Supreme Court held that Article 4 of the Torture 
Adjei, W.E., (2020)

The development of individual criminal responsibility under international law: Lessons from Nuremberg and Tokyo war crimes trials

Convention obliging every state party to ensure that all acts of torture are offenses under its criminal law had not been fully implemented in Senegal.

The reasoning of the Supreme Court is without legal basis in that the ground of jurisdiction provided for in Article 6 of the Convention, on the principle of forum deprehensionis (or jurisdiction of the place where the accused is apprehended), did not need to be translated into an express provision of national legislation to become operational [107]. The above case borders between politics and law because as soon as a new president of the Supreme Court was elected, the president of the Supreme Court was changed and that is when the Court held that Senegal had no jurisdiction over Habre [108]. It is clear from Habre case that political considerations are also a factor in limiting the effectiveness of the national courts in prosecuting international crimes.

\section{(c) Legislation granting amnesty}

Many states have passed legislation granting amnesty with regard to specific crimes - like war crimes or crimes against humanity or broad categories of crimes that include human rights abuses. After the enactment of such laws, conduct that was previously criminal is rectified with the consequence that criminal prosecution is withdrawn and the subsequent sentence is retired. One such example is the Lome Peace Agreement of July 7, 1999 between the Sierra Leone Revolutionary United Front (RUF) and the Government, granting extensive amnesty to the former [109]. The scope of this study does not extend to an extensive overview of Amnesty. However, suffice to mention that, amnesty treaties have as their underpinnings the principle of respect for state sovereignty and its implication that the power to decide who may be exempted from criminal punishment belongs to the sovereign prerogative of each state.

\section{(d) Statutes of limitation}

Another barrier to national jurisdiction and prosecution is statutes of limitation. In some states, the general provisions on the statutes of limitation also apply to at least some classes of international crimes. In Italy, for instance, the 20 years statutes of limitation apply to such international crimes as war crimes, crimes against humanity and genocide as long as they do not entail a sentence of life imprisonment [110]. The application of statutes of limitation is an impediment to the obligation of states to prosecute individual perpetrators of human rights and international humanitarian crimes [111]. The emphasis here is that though national courts have the principal responsibility of prosecuting individuals responsible for violation of serious crimes in national courts, there are impediments that hamper prosecution of such individuals. In order to overcome these obstacles, states should adhere to the principles enumerated in the international conventions and treaties proscribing international criminals, irrespective of the status of the culprit.

84 S sciendo Journal of Legal Studies Volume 25 Issue 39/2020 ISSN 2457-9017; Online ISSN 2392-7054. 
Adjei, W.E., (2020)

"Vasile Goldiş" Western University of Arad

The development of individual criminal responsibility under international law: Lessons from Nuremberg and Tokyo war crimes trials

\section{Conclusions}

It is important to stress, as noted at the outset, that the enforcement of "individual criminal responsibility" for the most serious crimes is the best way to protect against abuses and injustices inflicted upon well-intentioned individuals. Critiques of the international criminal justice system, which have become particularly manifest in the context of immunity and sovereignty, have essentially focused on institutions, in particular the international criminal prosecutions, accused of being a "threat" to state sovereignty. Although historically, there were few international duties placed on individuals, I have suggested in this essay that the Nuremberg, Tokyo and ICC trials have shattered the notion of immunity that could hide behind the apparatus of the state [112]. Thus, although sovereignty is a constitutional principle, international tribunals and various courts have addressed questions of impunity that are central to international criminal law jurisprudence. For example, "no one is above the law" was confirmed when the British House of Lords ruled that Augusto Pinochet had no right to immunity from prosecution as a former head of state. Importantly, the aim of this essay has been to articulate and highlight the enormous importance of an adequate judicial mechanism and mode of punishment and enforcement which would prevent those guilty of international crimes on this massive scale.

It is in this context then that an attempt will be made in this concluding chapter to indicate briefly, in the light of the foregoing inquiry, what are likely to be some of the more general problems which can be expected to loom large on the enforcement of individual criminal responsibility at both international and national levels.

Commentators have undoubtedly upheld that the development of international criminal law and the establishment of international tribunals, with jurisdiction over gross human rights violations, provide the international community with a potentially strong tool to fight impunity for the perpetrators of these war crimes. It still remains sufficiently apparent that there is an ever-increasing area within which the idea of individual criminal responsibility will have a major role to play in international criminal justice systems, most notably from national judicial systems. The creation of international tribunals to deal with these crimes is indeed an indication of the fact that universal jurisdiction is first and foremost an effective road to global security, peace and political stability; and in particular, justice for victims who suffer gravely under irresponsible political leaders and tyrannical rule. Undoubtedly, in an ideal world, personal culpability and punishment of individual offenders will serve as the best retribution and deterrence as the primary objectives of punishment at various established tribunals and courts.

Among the various other issues raised in the cases discussed in this essay was the question of whether the lessons of the Nuremberg, Tokyo and the ICC have a more particular application and relevance. Although doubts have been expressed by 
various scholars as to the legality of these court proceedings, this can surely only be on the footing that law is an essentially static concept that cannot develop to meet new situations [113]. This clearly has implications for any possible entrenchment of a document such as the Rome Statute 1998. Be that as it may, national amnesties, immunities, pardons or similar national measures to prevent a person from being accountable or being brought to justice for these atrocious of humanitarian crimes not only have no place in the international system of justice, but also are prohibited under international law. To make individuals accountable for international crimes committed requires States Parties efforts aimed at promoting principles, rules and governmental policies designed to secure political and legal protection of the individual, who is to a large extent the victim of acts of these crimes. It is, therefore, incumbent upon all states to acknowledge their obligations to the international community and commit themselves to the prosecution and punishment of the perpetrators of human rights atrocities in order to permanently end and deter the "powerful" against the "vulnerable" in the society [114]. It is widely acknowledged that the use of national courts to enforce international law has advantages for both domestic justice systems and the individual.

Needless to say, the development of individual criminal responsibility requires us to decide what vision of accountability should animate future constitutional thought and practice. As highlighted earlier, there is room for improvement in many areas. These include the quality of implementing legislation, the contribution of national courts in preventing international crimes; the development of a code of international criminal procedure which borrows elements from both the civilian and common law systems. The significance of these has been illustrated by the International Criminal Court (ICC) in its most recent decision, the Prosecutor v. Bosco Ntaganda (2019) which has focused on extensive involvement of the victims in the litigation processes. The approach adopted by the Court in this case should be seen as part of an ongoing philosophy of law. Moreover, the proceedings at Nuremberg after the last war against the Nazi war criminals showed the need for a modern version of international crimes coupled with adequate judicial mechanisms and mode of punishment and enforcement which would prevent those guilty of crimes of this massive scale.

\section{Acknowledgments}

The author thanks the anonymous reviewers and editor for their valuable contribution.

\section{Funding}

This research received no specific grant from any funding agency in the public, commercial, or not - for - profit sectors. 
Adjei, W.E., (2020)

"Vasile Goldiş" Western University of Arad

The development of individual criminal responsibility under international law: Lessons from Nuremberg and Tokyo war crimes trials

\section{Author Contributions}

The entire article was written by William Edward Adjei.

\section{Disclosure Statement}

The authors have not any competing financial, professional, or personal interests from other parties.

\section{References}

1. “Correspondents' Reports", Yearbook of International Humanitarian Law, 2009.

2. "Germane Considerations, "Individual Criminal Responsibility for Core International Crimes, 2008.

3. "International Human Rights to Conscientious Objection to Military Service and Individual Duties to Disobey Manifestly Illegal Order", Springer Science and Business Media LLC, 2009.

4. "Netherlands Yearbook of International Law, Volume 41, 2010”, Springer Science and Business Media LLC, 2011.

5. "Nigerian Yearbook of International Law 2017", Springer Science and Business Media LLC, 2018.

6. "United Kingdom House of Lords: Regina v. Bartle and the Commissioner of Police for the Metropolis and Others Ex Parte Pinochet", International Legal Materials, 2017.

7. "Yearbook of International Humanitarian Law, Volume 18, 2015", Springer Science and Business Media LLC, 2016.

8. Ainley, K., (2011). The International Criminal Court on Trial”, Cambridge Review of International Affairs.

9. Akande, D., (2003), The Jurisdiction of the International Criminal Court over Nationals of Non-Parties: Legal Basis and Limits, Journal of International Criminal Justice.

10. Bankas, E., (2005), The State Immunity Controversy in International Law: Private Suits against Sovereign States in Domestic Courts, Springer Science and Business Media LLC.

11. Bartels, R., (2015). Denying Humanitarian Access as an International Crime in Times of Non-International Armed Conflict: The Challenges to Prosecute and Some Proposals for the Future, Isr Law Review.

12. Beigbeder, Y., (2011). International Criminal Tribunals", Springer Science and Business Media LLC.

13. Bianchi, A, (1999). Immunity versus Human Rights: The Pinochet Case, European Journal of International Law.

14. Brouwer, A.M., (2015). The Problem of Witness Interference before International Criminal Tribunals", International Criminal Law Review.

15. Cakmak, C., (2017). A Brief History of International Criminal Laws and International Criminal Court, Springer Science and Business Media, LLC.

16. Cryer, R., (2001). The Boundaries of Liability in International Criminal Law, or Selectivity by Stealth, Journal of Conflict and Security Law.

17. Damgaard, C., (2008). Individual Criminal Responsibility for Core International Crimes, Springer Science and Business Media, LLC. 
Adjei, W.E., (2020)

"Vasile Goldiş" Western University of Arad

The development of individual criminal responsibility under international law: Lessons from Nuremberg and Tokyo war crimes trials

18. Deen-Racsmany, Z., (2005). The Status of the Special Court for Sierra Leone and Its Implications for Immunity, Leiden Journal of International Law.

19. Elagab, Y.O., (2004). The Special Court for Sierra Leone: Some Constraints, The International Journal of Human Rights.

20. Fairlie, A. M., (2005). Adding Fuel to Milosevic's Fire: How the use of Substitute Judges Discredits the UN War Crimes Tribunals, Criminal Law Forum.

21. Gil, A., Maculan, E., (2015). Current Trends in the Definition of 'Perpetrator' by the International Criminal Court: From the Decision on the Confirmation of Charges in the Lubanga Case to the Katanga Judgment", Leiden Journal of International Law.

22. Gillroy, M.J., (2013). An Evolutionary Paradigm for International Law, Springer Science and Business Media LLC.

23. Greppi, E., (2010), The Evolution of Individual Criminal Responsibility under International Law, International Review of the Red Cross, Volume 81, Issue 835.

24. Gutierrez Posse, D. T. H., (2006). The Relationship between International Humanitarian Law and the International Criminal Tribunals, International Review of the Red Cross.

25. Huong, T.T.P., (2012). A Changing Notion of Complementarity under the Rome Statute of the International Criminal Court.

26. Imoedemhe, O.C., (2017). The Complementarity Regime of the International Criminal Court, Springer Science and Business Media LLC.

27. Ingadottir, T., (2014). The Role of the International Court of Justice in the Enforcement of the Obligation of States to Investigate and Prosecute Serious Crimes at the National Level, Israel Law Review.

28. Kamari, C., (2015). Refiguring the Perpetrator: Culpability History and International Criminal Law's Impunity gap, International Journal of Human Rights.

29. Kaye, D., (2014). Archiving Justice: Conceptualizing the Archives of the United Nations International Criminal Tribunal for the Former Yugoslavia, Archival Science.

30. Kochavi, J. A., (2006). Israel and the International Legal Arena, Journal of Israel History. 31. Marchuk, I., (2014). The Fundamental Concept of Crime in International Criminal Law, Springer Science and Business Media LLC.

32. Marcus, J., (2015). Duress: From Nuremberg to the International Criminal Court, Finding the Balance between Justification and Excuse, Leiden Journal of International Law.

33. Meernik, J., (2004), Reaching Inside the State: International Law and Superior Liability, International Studies Perspectives.

34. Meloni, C., (2017). Modes of Responsibility (Article 28N) Individual Criminal Responsibility (Article 46B) and Corporate Criminal Liability (Article 46C).

35. Mohamed, S., (2015). Deviance, Aspiration and the Stories we Tell: Reconciling Mass Atrocity and Criminal Law, Yale Law Journal.

36. Nouwen, M. H. S., (2005). The Special Court for Sierra Leone and the Immunity of Taylor: The Case Continued, Leiden Journal of International Law.

37. O'keefe, R., (2011). The United State and the ICC: The Force and Farce of the Legal Arguments, Cambridge Review of International Affairs.

38. Palmer, G. M., (2004). Compensation for Vietnam's Agent Orange Victims, International Journal of Human Rights.

88 sciendo Journal of Legal Studies Volume 25 Issue 39/2020 ISSN 2457-9017; Online ISSN 2392-7054.

Web: publicatii.uvvg.ro/index.php/jls. Pages $69-97$ 
Adjei, W.E., (2020)

"Vasile Goldiş" Western University of Arad

The development of individual criminal responsibility under international law: Lessons from Nuremberg and Tokyo war crimes trials

39. Pita, J. C., Schimmeipenninck, O., (2004). A Surinam Crime before Dutch Court: PostColonial Injustice or Universal Jurisdiction? Leiden Journal of International Law.

40. Relva, H., (2003). The Implementation of the Rome Statute in Latin American States, Leiden Journal of International Law.

41. Sander, B., (2010). Unravelling the Confusion Concerning Successor Superior Responsibility in the ICTY Jurisprudence, Leiden Journal of International Law.

42. Sands, P., (2003). International Law Transformed? From Pinochet to Congo ......?, Leiden Journal of International Law.

43. Sangkul, K., (2016). Collective Genocidal Intent and Genocide as a Criminal Enterprise. 44. Sato, H., (2011). The Execution of Illegal Order and International Criminal Responsibility, Springer Science and Business Media LLC.

45. Steer, C., (2017). Translating Guilt, Springer Science and Business Media LLC.

46. Stephen, P.J., (2014). Collective Criminality and Individual Responsibility: The Constraints of Interpretation, Fordham International Law Journal, Volume 37, Issue 2.

47. Swaak-Goldman, O., (2008), Recent Developments in International Criminal Law: Trying to Stay Afloat between Scylia and Charybdis, International and Comparative Law Quarterly.

48. Tijs, K., Lachezar, Y., (2013). Divided Minds in the Lubanga Trial Judgment: A Case against the Joint Control Theory, International Criminal Law Review.

49. Vanacore, G., (2015). Legality, Culpability and Dogmatik: A Dialogue between the ECtHR, Comparative and International Criminal Law, International Criminal Law Review.

50. von Bogdandy, A., Wolfrum, R., (2009), Max Planck Institute of Comparative Public Law and International Law, Springer Science and Business Media LLC.

51. Williamson, J.A., (2008). Some Considerations on Command Responsibility and Criminal Liability, International Review of the Red Cross, Volume 90, No. 870.

52. Wouters, J., (2003). The Judgment of the International Court of Justice in the Case: Some Critical Remarks, Leiden Journal of International Law.

Online Sources:

1. www.jus.uio.no.

2. www.nycbar.org.

3. www.gistprobono.org.

4. www.usazeris.org.

5. www.hrc.upeace.org.

6. www.pulp.up.ac.za.

7. www.ilsa.org.

8. www.buponline.com.

9. www.cambridge.org.

10. www.gov.harvard.edu.

11. www.internationallawobserver.eu.

12. www.wcl.american.edu.

13. www.oup.com.

14. www.intelros.ru. 
Adjei, W.E., (2020)

\section{Notes}

[1] See Tom Farer, "Humanitarian Law and Armed Conflicts: Toward the Definition of "International Armed Conflict", Columbia Law Review, vol.71 (1971), p. 37 at p. 39; HansPeter-Gasser, "International Humanitarian Law", in Introduction to International Humanitarian Law (eds.), M.K. Balachandran, Rose Verghese. Also for the definition of genocide and crimes against humanity, see Rome Statute of the International Criminal Court (1998), as corrected by process-verbaux of 10 November 1998, 12 July 1999, 30 November 1999, 8 May 2000, 17 January 2001 and 16 January 2002. Is also available at www.1cccpi.int/about/Official_journal.html.

[2] For further information about the evolution of international criminal law principles, see M. Shaw, International Law, 6th edition (Cambridge: Cambridge University Press, 2008); Relva Hugo, "The Implementation of the Rome Statute in Latin American States," Leiden Journal of International Law, 2003; Edoardo Greppi, "The Evolution of Individual Criminal Responsibility under International Law," International Review of the Red Cross, Volume 81, Issue 835, April 2010; Tijs Kooijmans and Lachezar Yanev," Divided Minds in the Lubanga Trial Judgment: A Case against the Joint Control Theory," International Criminal Law Review, January 2013; Fairlie A. Megan, "Adding Fuel to Milosevic's Fire: How the use of Substitute Judges Discredits the UN War Crimes Tribunals", Criminal Law Forum, 2005.

[3] See Opening Speech of the Chief Prosecutor for the United States, reprinted in Trial of German Major War Criminals by the International Military Tribunal Sitting at Nuremberg Germany (Buffalo: William S. Hein \& Co., 2001), at 45.

[4] For further reading, see the Statute of the International Tribunal for the Prosecution of Persons Responsible for Serious Violations of International Humanitarian Law Committed in the Territory of the Former Yugoslavia, 1993 (ICTY), arts 1-7 of which provides that the Tribunal has jurisdiction to find natural persons individually responsible for certain international crimes. Similarly, see arts 1-6 of the Statute of the International Tribunal for the Prosecution of Persons Responsible for Genocide and Other Serious Violations of International Humanitarian Law Committed in the Territory of Rwanda and Rwandan Citizens Responsible for Genocide and Other Such violations Committed in the Territory of Neighbouring States, between 1 January 1994 and 31 December 1994 (ICTR).

[5] For further reading, see Preamble of the Rome Statute, para. 4.

[6] No.: ICC-01/04-02/06, 7 November 2019.

[7] See also Bemba Sentencing Judgment, para. 11; Al Mahdi Judgment, para. 67; and Bemba et al. Sentencing Judgment, para. 19.

[8] For further discussion, see M. Shaw, International Law, 6th edition (Cambridge: Cambridge University Press, 2008); for further reading, see, for example, Versailles Treaty of 1919 (Article 227); the Charter of the International Tribunal at Nuremberg (Article 7); the Statute of the Yugoslavia and Rwanda Tribunals (Articles $7 \& 6$ ) respectively; the Statute for the Special Court for Sierra Leone (Article 6(2)); and the Rome Statute of the International Criminal Court (Article 27).

[9] For further reading on international criminal law and individual criminal responsibility, see Cassese, A., International Law, 2nd edn. (Oxford: Oxford University Press, 2008); Dinstein Y., The Conduct of Hostilities under the Law of International Armed

90 sciendo Journal of Legal Studies Volume 25 Issue 39/2020 ISSN 2457-9017; Online ISSN 2392-7054.

Web: publicatii.uvvg.ro/index.php/jls. Pages $69-97$ 
Adjei, W.E., (2020)

"Vasile Goldiş" Western University of Arad

The development of individual criminal responsibility under international law: Lessons from Nuremberg and Tokyo war crimes trials

Conflict (Cambridge: Cambridge University Press, 2004); Henckaerts, J., and DoswaldBeck, L., Customary International Humanitarian Law, Vol. 1 (Cambridge: Cambridge University Press, 2004); Moir, L., The Law of Internal Armed Conflict (Cambridge: Cambridge University Press, 2002); Roberts, A., and Guelff, R., Documents on the Laws of War (Oxford: Oxford University Press, 2002); Shaw, M., International Law, 6th edn. (Cambridge: Cambridge University Press, 2008).

[10] Pinochet v. House of Lords (1998), House of Lords: For additional information, see Amnesty International USA, http://www.amnestyusa.org/internationaljustice. For the first time in history, a head of the state was held responsible as a person in Pinochet case in the United Kingdom. A former head of state was stripped of his immunity and put on trial before The British House of Lords in 1999.

[11] Prosecutor v. Kambanda: Case No. ICTR 97-23-S, (1998): ICTR.

[12] Prosecutor v. Tadic, Case No., IT-94-I-A, Judgment 191 (International Criminal Tribunal for the Former Yugoslavia July 15, 1999), also available at http://www.icty.org/x/cases/taic/acjug/en/tad-aj990715e.pdf.

[13] Arrest Warrant of 11 April 2000: (Democratic Republic of Congo v. Belgium) (2002),

ICJ.

[14] Zsuzsanna Deen-Rosemary, "Prosecutor v. Taylor: The Status of the Special Court for Sierra Leone and its Implications for Immunity" (2005) 18 Leiden Journal of International Law 299-322.

[15] No.: ICC-01/05-01/08, judgment pursuant to Article 74 of the Statute, 21 March 2016.

[16] No.: ICC-01/04-02/06.

[17] Philippe Kirsch, The Role of the International Criminal Court in Enforcing International Criminal Law, International Law Review, Volume 22, No. 4, Article 3 (2007) 539-547.

[18] This is cited by Andres Clapham in From Nuremberg to The Hague: The Future of International Criminal Justice, Philippe Sands, Cambridge University Press, 2003, p 31. See also Ingadottir Thordis, "The Role of the International Court of Justice in the Enforcement of the Obligation of States to Investigate and Prosecute Serious Crimes at the National Level," Israel Law Review, 2014.

[19] The ICTR has jurisdiction to prosecute people accused of genocide, crimes against humanity and war crimes committed in Rwanda between 1 January and December 1994. Also available at http://69.94.11.53/default.htm.

[20] Note: The ICTY was established in 1993, and has jurisdiction to prosecute war crimes, crimes against humanity and genocide committed after 1991 in the former Yugoslavia. Available at http://www.un.org/icty.

[21] Cambodia (since 2003).

[22] Note: Iraqi Special Tribunal which, although it is an Iraqi court, the Statute for the court was drafted by international lawyers and there is international participation in the trials. [23] Bruce Broomhall, International Justice and the International Criminal Court: Between Sovereignty and the Rule of Law. Oxford: Oxford University Press, 2003, 45-51.

[24] For further reading on case-law relating to criminal prosecution and immunities, see R. Bow Street Magistrate, ex parte Pinochet (No.3); Arrest Warrant of 11 April 2000 and 
Adjei, W.E., (2020)

The development of individual criminal responsibility under international law: Lessons from Nuremberg and Tokyo war crimes trials

Democratic Republic of Congo v. Belgium. Prosecutor v. Tadic, Case No, IT-94-I-A, Judgment 191 (International Criminal Tribunal for the Former Yugoslavia, July 15, 1999).

[25] See Yearbook of the International Law Commission, vol. II, 1954. Also see Yearbook of the International Law Commission, 1996, Volume II, Part 2.

[26] Text in Yearbook of the International Law Commission vol. II (2), 1996.

[27] Kriangsak Kittichaisaree, International Criminal Law, (Oxford University Press, 2001) p. 233.

[28] See for example, T. Meron, "War Crimes in Yugoslavia and the development of international law", AJIL, 1994, P. 70; A. Cassese, "The International Tribunal for the Former Yugoslavia and the implementation of international humanitarian law, p. 229.

[29] Case No. IT-94-1-A: App.Ch. 15 July 1999.

[30] Ibid, Case No. IT-94-I,Trial Chamber II, Opinion and judgment, 7 May 1997, paras. 704-710.

[31] Ibid, paragraph 186. Article 7(1) of ICTY Statute provides: A person who planned, instigated, ordered, committed or otherwise aided and abetted in the planning, preparation or execution of a crime referred to in Article 2 to 5 of the present Statute, shall be individually responsible for the crime. This Article is similar to Article 6(1) of the ICTY Statute.

[32] UN Doc. A/CONF 183/9; Final Act: UN Doc. A/CONF.183/10; See also F. Lattanzi (ed.). The International Criminal Court: Comments on the Draft Statute, Napoli, 1998; F. Lattanzi/E. Sciso (ed.), Dai Tribunali penali internazionali ad; Gerhar Werle, "Individual Criminal Responsibility in Article 25 ICC Statute," Journal of International Criminal Justice, Volume 5, Issue 4, September 2007, also available at: http://doi.org/10.1093/jicj/mqm059.

[33] Article 25(1) of the ICC Statute.

[34] Ibid, Article 25 (2). Further, the Geneva Conventions and the Convention against Torture place a legally binding obligation on states that have ratified them to exercise universal jurisdiction over persons accused of grave breaches of the Geneva Conventions and torture or to extradite them to a country that will.

[35] Article 25 (3) lists individuals who can be criminally liable which provides: In accordance with this Statute, a person shall be criminally responsible and liable for punishment for a crime within the jurisdiction of the Court if that person:

(a) Commits such a crime, whether as an individual, jointly with another or through another person, regardless of whether that other person is responsible;

(b) Orders, solicits or induces the commission of such a crime which in fact occurs or is attempted;

(c) For the purpose of facilitating the commission of such a crime, aids, abets or otherwise assists in its commission, including providing the means for its commission;

(d) In any other way contributes to the commission or attempted commission of such a crime by a group of persons acting with a common purpose. Such contribution shall be intentional and shall either:

(i) Be made with the aim of furthering the criminal activity or criminal purpose of the group, where such activity or purpose involves the commission of a crime within the jurisdiction of the Court; or

(ii) Be made in the knowledge of the intention of the group to commit the crime;

92 Sciendo Journal of Legal Studies Volume 25 Issue 39/2020 ISSN 2457-9017; Online ISSN 2392-7054.

Web: publicatii.uvvg.ro/index.php/jls. Pages $69-97$ 
Adjei, W.E., (2020)

"Vasile Goldiş" Western University of Arad

The development of individual criminal responsibility under international law: Lessons from Nuremberg and Tokyo war crimes trials

(e) In respect of the crime of genocide, directly and publicly incites others to commit the crime;

(f) Attempts to commit such a crime by taking action that commences its execution by means of a substantial step, but the crime does not occur because of circumstances independent of the person's intention. However, a person who abandons the effort to commit the crime or otherwise prevents the completion of the crime shall not be liable for punishment under this Statute for the attempt to commit that crime if that person completely and voluntarily gave up the criminal purpose.

[36] M. C. Bassiouni, (supra note 39), at 269-273.

[37] Rupa Bhattacharyya, "Establishing a Rule-of-Law: International Criminal Justice System" (1996) 31 Tex. Int'I L.J. 57, at 59; See also M. C. Bassiouni, "World War I, "The War to End all Wars" and the Birth of a Handicapped International Criminal Justice System", 30 Denver Journal of International Law and Policy (2002) 244, at 269-273.

[38] The German government refused to surrender its citizens to the allied powers who eventually acquiesced to the German government demand to try the accused in its own national courts where most of them escaped justice.

[39] Ibid.

[40] Agreement for the Prosecution and Punishment of the Major War Criminals of the European Axis, with annexed Charter of the International Military Tribunal, (hereinafter the 'London Charter'), 82 UNTS 279, 59 Stat. 1544, 8 August 1945.

[41] Note - Article 1 of the London Agreement for the Prosecution and Punishment of the Major War Criminals of the European Axis, of 8 August 1945, in D. Schindler/J. Toman, The Laws of Armed Conflicts: A Collection of Conventions, Resolutions and other Documents, Martinus Nijhoff/Henry Dunant Institute, Dordrecht/ Geneva, 3rd ed., 1988, p.5. [42] Agreement for the Prosecution and Punishment of Major War Criminals of the European Axis, August 8, 1945, Charter of the International Military Tribunal, 59 Stat. 1544, 1546, 82 U.N.T.S 279, 284 (hereinafter Nuremberg), cited in Rupa Bhattacharyya, supra, note 31, at 60. See also K. J. Heller, Retreat from Nuremberg: The Leadership Requirement in the Crime of Aggression”, 18 The European Journal of International Law (2007) 477-497, at 479 .

[43] "Article 6 of the Nuremberg Charter has since come to represent general international law." I. Brownlie, Principles of Public International Law, Oxford, 1991, p. 562, Along the same lines, M. Shaw, International Law, Cambridge, 1998, p. 471; Daillier/Pellet, p.677.

[44] Article 6 of the Charter of IMT provided that: The Tribunal established by the Agreement referred to in Article 1.

[45] Ian Brownlie, Principles of Public International Law 5th Eds. Oxford University Press, 1998566.

[46] Kevin Jon Heller, "What is an International Crime? (A Revisionist History), Volume 58, No. 2, Spring 2017, at 478; for further discussion on superior orders, see Sander Barrie, "Unravelling the Confusion Concerning Successor Superior Responsibility in the ICTY Jurisprudence", Leiden Journal of International Law, 2010.

[47] See IMT Judgment, at 223. 
Adjei, W.E., (2020)

The development of individual criminal responsibility under international law: Lessons from Nuremberg and Tokyo war crimes trials

[48] Schindler/Toman, "The Laws of Armed Conflicts: A Collection of Convention, Resolutions and other Documents, Martinus Nijhoff/Henry Dunant Institute, Dordrecht/Geneva, 3rd ed., 1988.

[49] Steven Ratner, supra note 3, at 22; see also Georg Schwarzenberger, "The Judgment of Nuremberg, 21 Tulane Law Review" (1946-1947) 329, at 348-49.

[50] Article 7 of the Charter provided that: "The official position of defendants, whether as Heads of State or responsible officials in Government departments, shall not be considered as freeing them from responsibility or mitigating punishment.

[51] Steven Ratner, Jason S. Abrams, "Accountability for Human Rights Atrocities in International Law: Beyond the Nuremberg Legacy" 2nd edn. (Oxford: Oxford University Press, 2001).

[52] Article 8 of the IMT Charter.

[53] Kriangsak Kittichaisaree, International Criminal Law, (Oxford University Press, 2001), p. 14. Hagenbach was individually held responsible for the crimes and sentenced to death.

[54] Mathew R. Lippman, "Humanitarian Law: The Development and Scope of the Superior Orders Defence” (2001-2002) 20 Penn. St. Int'l L. Rev. 153, at 178.

[55] L. S. Sunga, Individual Responsibility in International Law for Serious Human Rights Violations, Martinus Nijhoff Publication, 1992, at 56.

[56] 11 Trials of War Criminals, Vol. XI, p. 1236 in Mathew R. Lippman, "Humanitarian Law: The Development and Scope of the Superior Orders Defence" (2001-2002) 20 Penn. St. Int'l L. Rev. 153, at 178.

[57] Robert Cryer, "The Boundaries of Liability in International Criminal Law or 'selectivity by stealth' (2001) 6 Journal of Conflict \& Security Law: No. 1, pp. 3-31, at 12.

[58] Principles III and IV.

[59] Ilias Bantekas and Susan Nash, "International Criminal Law," 2nd edn. (Cavendish Publishing, 2003), 327.

[60] Mikhail Wladimiroff, "Former Heads of State on Trial" (2005) 38 Cornell International Law Journal 949, at 956.

[61] E. Van Sliedregt, "The Criminal Responsibility of Individuals for Violations of International Humanitarian Law (T.M.C. Asser Press: The Hague, 2003), 119.

[62] 327 U.S. (1946): 1. 40 Am. J. Int'1 L. 432-480 (April 1946).

[63] E. Van Sliedregt, supra note 80, at 122.

[64] Article 87 of the First Additional Protocol to the Geneva Conventions of 1949; oblige military commanders to prevent and repress crimes.

[65] Note: the Rome Statute of the International Criminal Court (ICC) established a permanent international criminal court to adjudicate the cases of persons charged with some of the most serious crimes of international concern.

[66] Mikhail Wladrimiroff, "Former Heads of State on Trial" (2005) 38 Cornell Int'l Law Journal 949.

[67] Article 28 (a) provides for military commanders and (b) for civilian superiors.

[68] Van Sliedregt, supra note, at 135.

94 sciendo Journal of Legal Studies Volume 25 Issue 39/2020 ISSN 2457-9017; Online ISSN 2392-7054.

Web: publicatii.uvvg.ro/index.php/jls. Pages $69-97$ 
Adjei, W.E., (2020)

"Vasile Goldiş" Western University of Arad

The development of individual criminal responsibility under international law: Lessons from Nuremberg and Tokyo war crimes trials

[69] Prosecutor v. Delalic: Case No. IT-96-21, Trial Chamber Judgment, 16 November 1998.

[70] Ibid., para. 356.

[71] Mikhail Wladimiroff, "Former Heads of States on Trial" (2005) 38 Cornell International Law Journal 949, at 956.

[72] Ibid.

[73] Ibid. Article 7 of the IMT Charter.

[74] Nuremberg Judgment, 22 Trial of the Major War Criminals before the International Military Tribunal 466 (1949), in Charles Pierson, "Pinochet and the End of Immunity: England's House of Lords that Former Head of State is not Immune from Torture" (2000) 14 Temple International and Comparative Law Journal 280, 284.

[75] Article IV of the Convention on the Prevention and Punishment of the Crime of Genocide, 1948.

[76] Article 2 (3) (a) of the International Covenant on Civil and Political Rights (ICCPR).

[77] R v. Bow Street Metropolitan Stipendiary Magistrate, ex parte Pinochet Ugarte (No 2) [2001] 1 A. C. 119, R. v Bow Street Stipendiary Magistrate Ex p. Pinochet Ugarte (No. 3) [2000]; R. v Bartle and the Commissioner of Police for the Metropolis Ex p. Pinochet, [1991] 2 All E.R. 97, R. v. Evans and the Commissioner of the Police for the Metropolis Ex p. Pinochet 24 March 1999, House of Lords; see further, Arrest Warrant of 11 April 2000 (Democratic Republic of Congo v. Belgium); Al Adsani v. United Kingdom 123 II.R 24; Jones v. Saudi Arabia 129 II.R 727; Saudi Arabia v. Nelson.

[78] See also AG of Israel v. Eichmann [1961] 36 I.L.R. 5.

[79] Indictment by the Prosecutor of the Tribunal against Slobodan Milosevic and Others, in Dr. Kristin Henrard, supra note, at 612.

[80] Case No. SCSL-2003-01-1, May 31, 2004, cited in Zsuzsanna Dean- Racsmany, "Prosecutor v. Taylor: The Status of the Special Court for Sierra Leone and Its Implications for Immunity" (2005) 18 Leiden Journal of International Law, 299-322, at 300 and 305-6. Also available at: http://www.sc-sl.org/Taylor.html. [Accessed July 5, 2006].

[81] Article 6 (2) of the SCSL Statute provides The official position of any accused persons, whether as Head of State or Government or as a responsible Government official, shall not relieve such a person of criminal responsibility nor mitigate punishment; available at http://www.sc-sl.org. [accessed 9 June 2010].

[82] Ibid.

[83] See Elies Van Sliedregt, The Criminal Responsibility of Individuals for Violations of International Humanitarian Law, The Hague (T.M.C Asser Press, 2003).

[84] Christopher C. Joyner, "Redressing Impunity for Human Rights Violations: The Universal Declaration and the Search for Accountability” (1997-1998) 26 Denv. J. Int'1 L. \& Pol'y 591, 608.

[85] See for example, Jose E. Alvarez, Crimes of States/Crimes of Hate: Lessons from Rwanda, 24 Yale Journal of International Law 365 (1999).

[86] See for example, Lynn Sellers Bickley, U.S. Resistance to the International Criminal Court: Is the Sword Mightier than the Law? 14 EMORY International Law Review, 213, 272-75 (2000); Leila Nadya Sadat \& S. Richard Carden, The New International Criminal 
Adjei, W.E., (2020)

The development of individual criminal responsibility under international law: Lessons from Nuremberg and Tokyo war crimes trials

Court: An Uneasy Revolution, 88 CEO. Law Journal: 381, 385 (2000); Andre Nollkaemper, "Internationally Wrongful Acts in Domestic Courts," The American Journal of International Law, Volume 101, No.4, October 2007.

[87] Kenneth C. Randall, "Universal Jurisdiction under International Law," (1987-1988): 66 Texas Law Review, 785.

[88] Cassese, at 284.

[89] Article 7(1) of the Torture Convention.

[90] R v. Bow Street Metropolitan Stipendiary Magistrate, ex parte Pinochet Ugarte, [2000] I.A.C. 147; For further reading see Charles Pierson, "Pinochet and the End of Immunity: England's House of Lords Holds that Former Head of State is Not Immune from Torture" (2000) 14 Temple International and Comparative Law Journal 263.

[91] Ibid. paras. 837-8.

[92] Attorney-General of Israel v. Eichmann, 36 I.L.R. 277 (Israel Supreme Court, 1962)

[93] Ibid. at 304.

[94] Antonio Cassese, International Criminal Law (Oxford University Press, 2003) p. 285.

[95] See for example, Jonathan I. Charney, "International Criminal Law and the Role of Domestic Courts", the American Journal of International Law, Vol. 95 no. 1 (Jan. 2001), pp. 120-124; Jose E. Alvarez, "Crimes of States/Crimes of Hate: Lessons from Rwanda," 24 Yale Journal of International Law 365 (1999); Lynn Sellers Bickley, U.S Resistance to the International Criminal Court: Is the Sword Mightier than the Law? 14 Emory Int'l Law Review, 213, 272-75 (2000); Leila Nadya Sadat \& S. Richard Carden, The New International Criminal Court: An Uneasy Revolution, 88 GEO. L. J. 381, 385 (2000).

[96] Dapo Akande, "International Law Immunities and the International Criminal Court" (2004) 98 Am. J. Int'1 L. 407, 409. See also: Paul G. Lauren, "From Impunity to Accountability: Forces of Transformation and the Changing International Human Rights Context," in Thakur Ramesh Chandra, From Sovereign Impunity to International Accountability: The Search for Justice in a World of States (United States Press, 2004).

[97] Immunity ratione personae, is the immunity enjoyed by certain categories of state officials by virtue of their office.

[98] Ghaddafi Case, 13 March 2001, No. 1414, Criminal Proceedings against Col. Muammar el-Ghaddafi, cited in Dapo Akande, Ibid, at 41. Also available at: http://www.ejil.org/journal/Vol12/No3/art2-01.html (accessed 16 March 2008).

[99] Ibid.

[100] Order (auto) of 4 March 1999, (No. 1999/2723): cited in Antonio Cassese, "When May Senior State Officials Be Tried for International Crimes? Some Comments on the Congo v. Belgium Case" (2002) 13 European Journal of International Law 853, at 860-861.

[101] International Court of Justice, 14 February 2002: General List No. 121.

[102] Ibid., para. 58.

[103] (Case No. SCSL-2003-01-1, Decision on Immunity from Jurisdiction, 31 May 2004, 128 II.R 239); See also United States case, Republic of Philippines v. Marcos (No. 1) where the US Court of Appeals for the Second Circuit held that the Marcoses, the deposed leader and his wife, were not entitled to sovereign immunity. This was supported in US v. Noriega where the District Court noted that head-of-state immunity was grounded in customary

96 Sciendo Journal of Legal Studies Volume 25 Issue 39/2020 ISSN 2457-9017; Online ISSN 2392-7054. Web: publicatii.uvvg.ro/index.php/jls. Pages $69-97$ 
Adjei, W.E., (2020)

"Vasile Goldiş" Western University of Arad

The development of individual criminal responsibility under international law: Lessons from Nuremberg and Tokyo war crimes trials

international law, but, in order to assert such immunity, a government official must be recognized as the head of state, which had not happened in this case.

[104] Court of Appeal of Paris, Judgment of 6th November 1995: cited in Cassese, Ibid, at 304.

[105] Case of Hissene Habre, Senegalese Supreme Court, 20 March 2001, cited in Cassese, Ibid., at 304. He was indicted by a Belgian court for war crimes, crimes against humanity and torture. In July 2006, in response to a request by the African Union, Senegal agreed to prosecute Hissene Habre.

[106] Article 6 of the 1984 Convention against Torture and Other Cruel, Inhuman or Degrading Treatment or Punishment, imposes on every state party on whose territory, an alleged torture, is present a duty to institute criminal proceedings against him.

[107] Cassese, supra note 99, at 307.

[108] Ruth Wedgwood, "Augusto Pinochet and International Law" (2000-2001): 46 McGill Law Journal 241, at 249. Habre was later indicted last year by a Belgian Judge and Belgium has requested his extradition from Senegal. Available at http://hrw.org/english/docs/2006/01/23/africa13615_txt.htm (accessed 14 July, 2016).

[109] Daryl A. Mundis, "New Mechanisms for the Enforcement of International Humanitarian Law" (2001): 95 Am. J. Int'1 L. 934, at 937. However, Article 10 of SCSL Statute states that a grant of amnesty is not a bar to prosecution by the Special Court. Provision on Amnesty under The Lome Cease Fire Agreement is provided for in Article IX thereof.

[110] Cassese, supra note 99, at 317.

[111] The UN Convention on Non-Applicability of Statutory Limitation to War Crimes and Crimes against Humanity, 1968, prohibits the application of statutes of limitation to war crimes, crimes against humanity or genocide.

[112] Jelena Pejic, "Creating a Permanent International Criminal Court: The Obstacles to Independence and Effectiveness" (1997-1998) 29 Columbia Human Rights Law Review 291, at 295. Notably, the material jurisdiction of the ICC is over four categories of crimes: Genocide, War crimes, Crimes against humanity, and Crimes against the administration of justice of the ICC.

[113] See G. Schwarzenberger, "The Problem of an International Criminal Law", in Current Legal Problems, vol. 3 (1950), p. 263.

[114] See for example, J. E. Hijman, The Concept of International Legal Personality: An Inquiry into the History and Theory of International Criminal Law (2004) or 5-6. See also Robert Cryer, International Criminal Law vs. State Sovereignty: Another Round? The European Journal of International Law Vol. 16 no. 5 979-1000: EJIL 2006. 